\title{
Translog Model Of Employment Substitution And Economies Of Scale In The U.S. Steel Industry, 2003
}

Amaechi N. Nwaokoro, (E-mail: anwaokoro@yahoo.com), Morehouse College

\begin{abstract}
The period of 1963-1988 witnessed a tremendous decline in U.S. steel employment while the real wage rate increased slightly in the industry. There is a popular notion that the nominal wage rate is the major factor in explaining the declining steel employment. This study examines the decline in a system of input demand equations based on time series data. The study identifies a heavy capitalization in the industry as the driving factor for the steel employment decline. This result supports the claim that the high wage rate in the industry is backed up by high productivity and therefore is not responsible for the steel employment decline. Also, the study finds a lot of input substitutions. The study finds diseconomies of scale in the industry, which may explain the decline of the industry.
\end{abstract}

\subsection{Introduction}

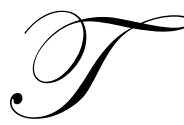

he period of 1963-1988 was critical for employment in the U.S. steel industry. During the period, the industry witnessed a tremendous decline in both the output and employment, and the real wage rate increased slightly. Barnett \& Crandall (1986, pp. 40-42) uses the trend of the nominal wage rate in the industry to claim that high wage rate is a major factor responsible for declining steel employment. Others argue that high productivity (output per worker) has always been associated with the high wage rates paid by the industry: see Barnett \& Schorsch, 1983, for example. Nominal wage rate could be rising without having a significant effect on unionized steel employment—a non-nominal value.

It is obvious that growing foreign competition has had a strong impact on steel output, which in turn has an adverse effect on steel employment. These impacts have been estimated by Nwaokoro (1996). In this paper, the view that declining steel employment is not driven by high wage rate but by the heavy capital requirement of the industry is examined.

Heavy capitalization started in the 1950s when investments in the industry went mainly to capital expansion while maintaining the existing technology (Barnett \& Schorsch 1983, pp. 13, 27). In the 1980s, the increasing use of new technologies by foreign competitors and most especially the Japanese adoption of modern technology such as the continuous casting of steel compelled the U.S. steel industry to invest in these technologies (Hogan, 1983, pp. 6$7,77,80,108-109)$. These technical changes have had a devastating impact on employment in the steel industry.

This paper addresses declining steel employment from the perspective of substitution of employment by heavy capitalization in the industry. The decline is examined by estimating the effect of the deflated wage rate, cost of capital, cost of materials, and cost of energy on factor demands. First, I develop a basic multifactor cost function for the steel sector. Properties of the cost function are examined including returns to scale and homotheticity. In addition, elasticities of substitution are constructed using the Allen Partial elasticities of substitution equations. This work follows the work of Berndt (1991), Griffin \& Gregory (1976), Garofalo \& Malhotra (1984), Turnovasky \& Donnelly (1984), Christensen \& Greene (1976) and Hamermesh (1993).

The study finds evidence of substitutability among inputs. Production and non-production workers are substitutes; materials and energy are substitutes, while non-production workers and capital are complements. 
Production employment is independent of the amount of capital used. With a heavy capitalization, an increase in the cost of capital will not lead to an appreciable impact on steel employment.

The rest of the study is laid out in three sections. Section II discusses the data and the sources. In section III, I discuss the fundamental issues of the translog cost function and the system of share equations. Estimating the share equations and testing the assumptions of production theory using the translog cost function form the basis of the discussion in section IV.

\subsection{Data and Sources}

The data are measured annually over the period from 1963 and to 1988 . These variables were obtained from three sources. The output variable represents the U.S. production of steel mill products. It is measured in net tons. ${ }^{1}$ The employment variable represents the production workers and is measured in thousands of workers. ${ }^{2}$ Another source of the variables is the Manufacturing Productivity Data (MP). ${ }^{3}$ The descriptive statistics of the major series are presented in Table 1.

Table 1: Summary statistics

\begin{tabular}{lccc}
\hline Variable Name & Mean & Standard Deviation & Interquatile Range $^{-1}$ \\
\hline Production Employment (thousands) $^{1}$ & 0.349 & 0.090 & 0.187 \\
Real Wage Rate $^{2}$ & $\$ 12.42$ & 1.12 & 2.40 \\
Labor Efficiency $^{3}$ & 30.18 & 5.56 & 5.52 \\
Observations: 26 & & & \\
\hline
\end{tabular}

T(Source: 1909-1990 issue of the U.S. Employment and Earnings Survey Data, U.S. Department of Labor.).

${ }^{2}$ (Source: U.S. Employment and Earnings Survey Data, 1909-1990 issue, U.S. Department of Labor.)

${ }^{3}$ (Source: Metal Statistics 1969, 1974, 1979, 1984 and 1990 series, American Metal Market.).

Figure 1 shows the time series plots from the relative values ${ }^{4}$ for employment, steel worker real wages rate, and labor efficiency.

Figure 1: Time Series of Wage, Employment, and Labor Efficiency

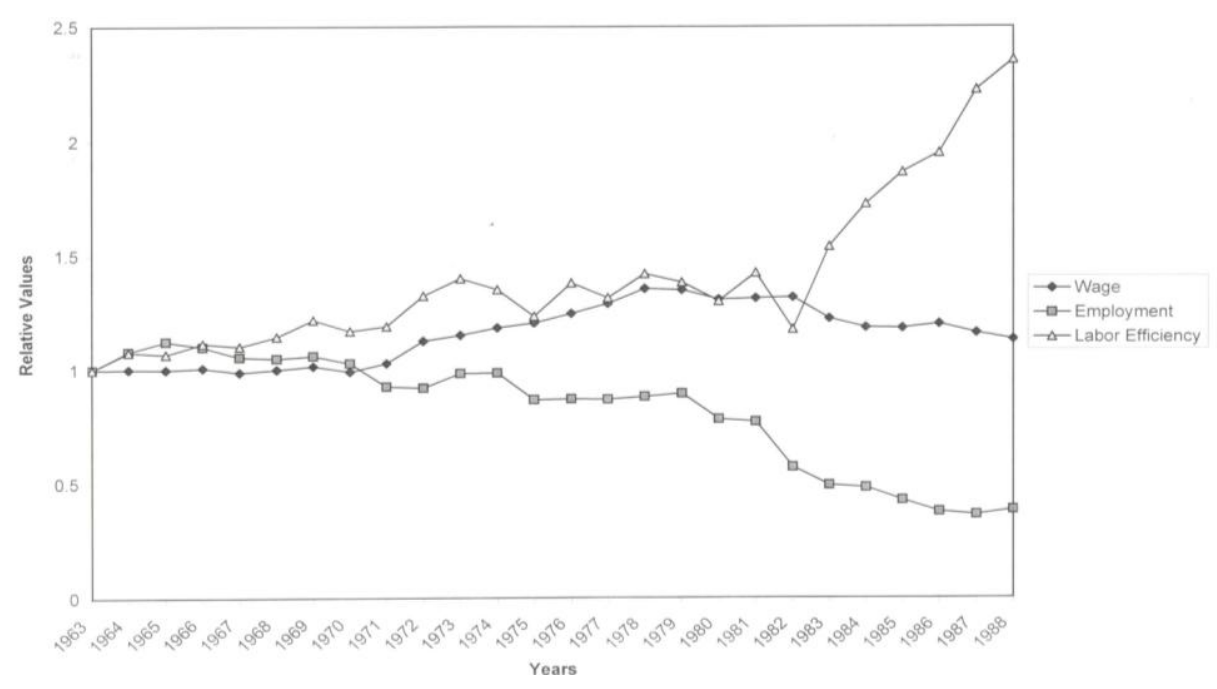

The decline in steel employment began in the period of 1979-1982. From the 1979 through 1988, employment declined by $-7.49 \%$. At the same time, the real wages in the industry have adjusted only modestly. 
Of special interest is the behavior of both real wage rate and employment in the period of 1983 to 1988 . Except in 1986, from 1983 to 1988, the real wage rate declines and the employment also declines in the same period except in 1988. These two variables do not identify the demand for labor. This issue here seems to be that the real wage rate and employment are not related.

Generally, before 1982, the labor efficiency factor exhibits an increasing trend, which becomes very sharp after 1982. During the period in study, compensations for capital increased by $5.94 \%$ while compensations for labor increased by $3.14 \%$. These stylized facts seem to indicate that capital is used as a substitute for labor.

\subsection{The Translog Cost Function and Share Equations}

A translog individual cost function is stated as:

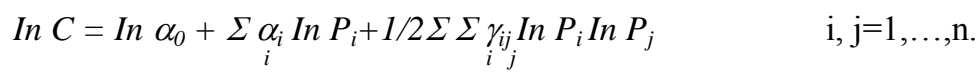

$\mathrm{C}$ is the minimum amount for producing a given amount of output (Q) from $n$ number of inputs - production worker (L), non-production worker $(\mathrm{N})$, capital-investment $(\mathrm{K})$, material $(\mathrm{M})$, and energy $(\mathrm{E})$, and $P_{i}$ and $P_{j}$ are the prices of the inputs. With the assumption of symmetry condition, an application of Shepherd Lemma in the translog cost function gives rise to the following linear demand equations that can be estimated.

$S_{i}=\alpha_{i}+\sum_{j} \gamma_{i j} \operatorname{In} P_{i}+\mu_{i} \quad \quad \mathrm{i}, \mathrm{j}=1, \ldots, \mathrm{n}$.

$\mathrm{S}_{\mathrm{i}}$ is the respective cost share of the inputs and $\mu_{\mathrm{i}}$ is the random error term in the cost minimization condition. Furthermore, the assumption of homogeneity of degree one in input prices, implies that:

$\sum_{i} \alpha_{i}=1$

and

$\Sigma_{i} \gamma_{i j}=0 \quad \mathrm{i}=1, \ldots, \mathrm{n}$.

Given symmetry condition,

$\gamma_{i j}=\gamma_{j i} \quad \mathrm{i}, \mathrm{j}=1, \ldots, \mathrm{n} \quad \mathrm{i} \neq \mathrm{j}$.

The imposed conditions explain that:

$\sum_{j} \gamma_{i j}=0 \quad \mathrm{j}=1, \ldots, \mathrm{n}$.

This implies that constant return to scale is assumed in specifying the translog. Given this assumption, testing for linear homogeneity is the same as testing for symmetry (Turnovsky \& Donnelly, 1984).

As pointed out by Berndt (1991, p. 472), estimation of equation (2) by OLS results in a singular and nondiagonal error covariance matrix. To avoid this, the factors prices of production workers, non-production workers, capital, and material are stated relative to the price of energy and the equation is reestimated. With the estimates from equation (2) given the relative prices, and from the symmetry and homogeneity of degree one in input prices conditions, the estimates of the share of energy are retrieved. 


\subsection{Estimating Cost Function and Share Equations}

The discussion here centers on estimating the share equations and on testing the assumptions imposed on the non-homothetic translog cost function.

Estimates from the System of Equation ${ }^{5}$ : Table 2 reports the estimates.

Table 2: Equation-by-Equation Maximum Likelihood (ML) Parameter

Estimates of Translog Share Equations (2) (standard errors in parentheses)

\begin{tabular}{|c|c|c|c|c|c|}
\hline$\alpha_{L}$ & $\begin{array}{l}-0.286 \\
(0.136)\end{array}$ & $\gamma_{\mathrm{LQ}}$ & $\begin{array}{l}0.002 \\
(0.010)\end{array}$ & $\gamma_{\mathrm{KQ}}$ & $\begin{array}{l}0.096^{*} \\
(0.015)\end{array}$ \\
\hline$\alpha_{N}$ & $\begin{array}{l}0.228 * \\
(0.068)\end{array}$ & $\gamma_{\mathrm{NL}}$ & $\begin{array}{l}0.066^{*} \\
(0.013)\end{array}$ & $\gamma_{\mathrm{ML}}$ & $\begin{array}{l}-0.137 * \\
(0.045)\end{array}$ \\
\hline$\alpha_{\mathrm{K}}$ & $\begin{array}{l}-1.289 * \\
(0.214)\end{array}$ & $\gamma_{\mathrm{NN}}$ & $\begin{array}{l}0.006 \\
(0.011)\end{array}$ & $\gamma_{\mathrm{MN}}$ & $\begin{array}{l}0.027 \\
(0.026)\end{array}$ \\
\hline$\alpha_{M}$ & $\begin{array}{l}1.513 * \\
(0.334)\end{array}$ & $\gamma_{\mathrm{NK}}$ & $\begin{array}{l}-0.074 * \\
(0.019)\end{array}$ & $\gamma_{\mathrm{MK}}$ & $\begin{array}{l}0.040 \\
(0.080)\end{array}$ \\
\hline$\alpha_{\mathrm{E}}$ & $\begin{array}{l}0.834 * \\
(0.224)\end{array}$ & $\gamma_{\mathrm{NM}}$ & $\begin{array}{l}0.027 \\
(0.026)\end{array}$ & $\gamma_{\mathrm{MM}}$ & $\begin{array}{l}-0.082 \\
(0.135)\end{array}$ \\
\hline$\alpha_{\mathrm{Q}}$ & $\begin{array}{l}11.260 * \\
(1.802)\end{array}$ & $\gamma_{\mathrm{NE}}$ & $\begin{array}{l}-0.025 \\
(0.032)\end{array}$ & $\gamma_{\mathrm{ME}}$ & $\begin{array}{l}0.152 * \\
(0.071)\end{array}$ \\
\hline$\gamma_{\mathrm{QQ}}$ & $\begin{array}{l}-0.615^{*} \\
(0.120)\end{array}$ & $\gamma_{\mathrm{NQ}}$ & $\begin{array}{l}-0.025^{*} \\
(0.005)\end{array}$ & $\gamma_{\mathrm{MQ}}$ & $\begin{array}{l}-0.038 \\
(0.022)\end{array}$ \\
\hline$\gamma_{\mathrm{LL}}$ & $\begin{array}{l}0.063 \\
(0.033)\end{array}$ & $\gamma_{\mathrm{KL}}$ & $\begin{array}{l}0.049 \\
(0.036)\end{array}$ & $\gamma_{\mathrm{EL}}$ & $\begin{array}{l}-0.041 \\
(0.081)\end{array}$ \\
\hline$\gamma_{\mathrm{LN}}$ & $\begin{array}{l}0.066^{*} \\
(0.013)\end{array}$ & $\gamma_{\mathrm{KN}}$ & $\begin{array}{c}-0.074 * \\
(0.0 .19)\end{array}$ & $\gamma_{\mathrm{EN}}$ & $\begin{array}{l}-0.025 \\
(0.032)\end{array}$ \\
\hline$\gamma_{\mathrm{LK}}$ & $\begin{array}{l}0.049 \\
(0.036)\end{array}$ & $\gamma_{\mathrm{KK}}$ & $\begin{array}{l}0.121 \\
(0.065)\end{array}$ & $\gamma_{\mathrm{EK}}$ & $\begin{array}{l}-0.136 \\
(0.084)\end{array}$ \\
\hline$\gamma_{\mathrm{LM}}$ & $\begin{array}{l}-0.137 * \\
(0.045)\end{array}$ & $\gamma_{\mathrm{KM}}$ & $\begin{array}{l}0.040 \\
(0.080)\end{array}$ & $\gamma_{\mathrm{EM}}$ & $\begin{array}{l}0.152 * \\
(0.071)\end{array}$ \\
\hline$\gamma_{\mathrm{LE}}$ & $\begin{array}{l}-0.041 \\
(0.081)\end{array}$ & $\gamma_{\mathrm{KE}}$ & $\begin{array}{l}-0.136 \\
(0.084)\end{array}$ & $\gamma_{\mathrm{EE}}$ & $\begin{array}{l}0.050 \\
(0.240)\end{array}$ \\
\hline & & & & $\gamma_{\mathrm{EQ}}$ & $\begin{array}{l}-0.035 \\
(0.040)\end{array}$ \\
\hline
\end{tabular}

*Denotes the estimates that are significant at the marginal probability level of 0.05 .

The significance of the estimates for the cost share of energy is verified in t-test. The estimates of the constant share elasticities describe the patterns of substitution among production workers, non-production workers, capital, materials, and energy inputs. For instance, $\gamma_{\mathrm{LN}}>0$ means that the share of production workers will increase with increase in the price of non-production workers.

By symmetry, $\gamma_{\mathrm{LN}}$, which is also interpreted as the share elasticity of non-production workers with respect to the price of production workers, means that the share of non-production workers will increase with increase in the price of production workers. Also, the estimate of $\gamma_{\mathrm{ME}}$ implies that the share of materials will increase with increase in the price of energy. This estimate contrasts the related estimate (-0.004) in Berndt (1991). The estimates of $\gamma_{\text {LM }}$ and $\gamma_{\mathrm{NK}}$ imply that the corresponding value shares will decrease with increase in the prices of materials and capital. The estimates of $\gamma_{\mathrm{LM}}$ are statistically consistent with the related estimate (-0.071) in Berndt (1991).

While the estimates of $\gamma_{\mathrm{KQ}}$ imply that the share of capital will increase with increase in output, the negative estimate of $\gamma_{\mathrm{NQ}}$ implies that the share of non-production workers will decrease with increase in output. The 
insignificant estimates indicate that change in their associated prices or output will not affect the corresponding cost shares. For example, the estimate of $\gamma_{\mathrm{LL}}$ implies that a change in the price of production labor has no effect on the cost share of labor. The estimate of $\gamma_{\mathrm{LK}}$ implies that a change in the price of production labor has no effect on the cost share of capital. Also, the estimate of $\gamma_{\mathrm{KK}}$ implies that a change in the price of capital has no effect on the cost share of capital. These insignificant effects arise because the industry is heavily capitalized.

The conclusion to be drawn here is that the steel industry is not characterized by employment substitution with respect to the price of labor but is characterized by substitutions especially in the use of production and nonproduction workers, capital and non-production workers, and production workers and materials. The input substitutions seem necessary for cost minimization. There is a clear evidence of heavy capitalization in the industry.

The Allen Partial Elasticities of Substitution: The objective here is to convert the significant price estimates in the translog cost function into Allen Partial elasticities of substitution and own-price elasticities (Allen 1938). These elasticities are stated as

$\sigma_{i i}=\left(S_{I} S_{j}+\gamma_{i j}\right) / S_{I} S_{j}$

$\sigma_{i j}=\left(S_{I}^{2}-S_{I}+\gamma_{i i}\right) / S_{I}^{2}$

As these show, the elasticities are derived from the parameter estimates of $\gamma_{\mathrm{ii}}$ 's and the factors' shares. The shares of the production workers, non-production workers, capital, material, and energy are the averages. Using the shares and the significant estimates from Table 1, the Allen Partial elasticities of substitution are calculated. ${ }^{6}$ The elasticities are given in Table 3.

The significant estimates imply the following about the relationship among the inputs. Insignificant estimate of $\sigma_{\mathrm{LK}}$ (6.114) indicates that with a heavy capitalization, an increase in the cost of capital will not lead to an appreciable impact on steel employment. The estimate of $\sigma_{\mathrm{LN}}$ shows that the production and non-production workers are substitutes. This estimate contrasts the related estimate (-0.48) in Turnovsky and Donnelly (1984). The estimate of $\sigma_{\mathrm{ME}}$ that is below the estimate (0.83) from Berndt (1991) implies that materials and energy are substitutes. With the estimate of $\sigma_{\mathrm{NK}}$, the non-production workers and capital are shown to be complements.

Testing Homotheticity and Constant Returns to Scale (CRS): A set of F-tests is used to assess the presence of homotheticity, homogeneity of a constant degree, and a constant returns to scale in the output of the translog cost function. First, the test is conducted in the presence of the production and non-production workers' real wage rates, cost of capital, price of materials, and output.

Table 3 : Allen Partial Elasticities of Substitution

\begin{tabular}{cll}
\hline Parameter & Estimate \\
\hline$\sigma_{\mathrm{LN}}$ & $8.530^{*}$ \\
& $\sigma_{\mathrm{LK}}$ & $(1.483)$ \\
& $\sigma_{\mathrm{NK}}$ & 6.114 \\
& & $(3.757)$ \\
& $\sigma_{\mathrm{ME}}$ & $-23.862^{*}$ \\
& $(6.384)$ \\
& $3.933^{*}$ \\
\end{tabular}

*Denotes the estimates that are significant at the marginal probability level of 0.05 . 
Test 1 is a test of homotheticity. The translog cost function is said to be homothetic if the interaction between the output variable and the factor prices are jointly tested to be equal to zero. With test 2 , I investigate the homogeneity of a constant degree in the output. The translog cost function is homogenous of a constant degree in output if the interaction between the output variable and the factor prices, and the interaction in the output itself are jointly tested to be equal to zero.

Finally, the scale economies, SCE-expressed as a proportional increase in cost as a result of a small proportional increase in the output-is constructed as $S C E=1-\partial \ln C / \partial \ln Q$ where $\partial \ln C / \partial \ln Q=\alpha_{Q}+\gamma_{L Q} \ln P_{L}+\gamma_{N Q}$ $\ln P_{N}+\gamma_{K Q} \ln P_{K}+\gamma_{M Q} \ln P_{M}+\gamma_{E Q} \ln P_{E}+\gamma_{Q Q} \ln Q$ (Christensen \& Greene 1976, Hamermesh 1993). $P_{i}$ and $Q$ are the averages. While a positive number for SCE implies positive scale economies, a negative number for SCE implies diseconomies of scale.

Table 4 reports the F-value estimates for tests 1 and 2.

Table 4: F-Tests

\begin{tabular}{clll}
\hline Test & $\begin{array}{l}\text { Numerator } \\
\text { Value }\end{array}$ & $\begin{array}{l}\text { Denominator } \\
\text { Value }\end{array}$ & F-Value \\
Test 1 & 25.383 & 10.614 & $2.391^{*}$ \\
Test 2 & 29.671 & 10.614 & $2.795^{*}$ \\
\hline
\end{tabular}

*Denotes the estimates that are significant at the marginal probability level of 0.05 .

The F-value estimates are significant at the marginal probability level of 0.05 . This means that in each case, the null hypothesis of the estimates being equal to zero is rejected. The idea here is that the cost function is nonhomothetic and does not exhibit constant returns to scale. The tests are repeated in the presence of production and non-production workers' real wage rates, cost of capital, and output. In this case the tests failed. A negative number (-0.946) for SCE implies diseconomies of scale. The suggestion here is that the translog cost function is nonhomothetic and there is decreasing return to scale.

In summary, employment substitution is not explained by the price of labor. This is contrary to the declining steel employment explanation with respect to nominal wage rate given in Barnett \& Crandall (1986). There is a clear interaction between production and non-production workers, capital and non-production workers, and materials and energy in the cost share models. The interaction is a clear indication of cost saving driven by the heavy capitalization in the industry. The translog cost function is non-homothetic and exhibits a decreasing return to scale.

\subsection{Suggestions for Future Research}

Future research must address the feasibility of having new technology, innovation, and labor as complements in the U.S. steel industry. Comparative studies on steel employment in the developing economies and Japan could explain how technology and new innovation can enhance U.S. steel labor employment. To further enhance the steel employment explanation, future research could utilize a multi-product cost function approach since this study utilizes only steel mill output in the cost function.

The author wishes to thank Dr. Mary Berth Walker for her insightful and useful comments and suggestions. The author is responsible for the expressed views in this paper. 


\subsection{Endnotes}

1 The source of this variable is Metal Statistics 1969, 1974 1979, 1984 and 1990 series.

2 The source of these variables is 1909-1990 issue of the U.S. Employment and Earnings Survey Data.

3 Both production and cost information, and indexed price deflators are provided in the set. The labor cost is divided by hourly employment to get the wage rate. The price deflators are for investment, cost of materials, and energy. All price variables are stated in the form of relative prices. Thus, I normalize the price deflators by industrial price index obtained from 1965 to 1990 series of The Economic Report of the President. The wage rate variable is deflated with the consumer Price Index (CPI) from the 1964 to 1990 series of The Economic report of the President.

4 Define a relative value as $X_{t} / X_{1963}$ where $X_{t}$ is the observation of period $t$ and $X_{1963}$ is the base year's observation.

$5 \quad$ The SAS SYSLIN procedure is used for estimating equation (2). Data is available upon request.

$6 \quad$ T-Test is applied to the estimates to verify if they are statistically significant.

\subsection{References}

1. Allen, R. G. D. 1938. Mathematical Analysis for Economists (2 ${ }^{\text {nd }}$ edition). Macmillian. London.

2. American Metal Market. 1969, 1974, 1979, 1984 and 1990. Metal Statistics. American Metal Market. New York.

3. Barnett, Donald F., and Robert W. Crandall. 1986. Up from the Ashes: The Rise of the Steel Minimill in the United States. The Brookings Institution. Washington, D.C.

4. Barnett, Donald F., and Louis Schorsch. 1983. Steel: Upheaveal in a Basic Industry. Ballinger Publishing Company. Cambridge, Massachusetts.

5. Bartelsman, Eric and Wayne Gray. 1994. NBER Manufacturing Productivity Database. Working Paper.

6. Berndt, Ernst. 1991. The Practice of Econometrics: Classic and Contemporary. Addison-Wesley Publishing Company Inc. Reading, Massachusetts.

7. Christensen, Laurits R., and William H. Greene. 1976. "Economies of Scale in U.S. Electric Power Generation.” Journal of Political Economy, 84: 655-676.

8. Garofalo, Gaspar, and Devinder Malhotra. 1984. "Input Substitution in the Manufacturing Sector during the 1970's: A Regional Analysis.” Journal of Regional Science, 24: 51-63.

9. Griffin, James M., and Paul R. Gregory. 1976. "An Intercountry Translog Model of Energy Substitution Responses." The American Economic Review, 66: 845-57.

10. Hamermesh, Daniel. 1993. Labor Demand. Princeton University Press. Princeton.

11. Hogan, William T. 1983. World Steel in the 1980s: A Case of Survival. Lexington Books, D.C. Heath and Company. Lexington, Massachusetts.

12. Nwaokoro, Amachi N. 1996. Labor Demand in the U.S. Steel Industry. Dissertation. University of Oklahoma

13. SAS/ETS. User's Guide, Version 6, $2^{\text {nd }}$ edition. SAS Institute Inc., Cary, North Carolina.

14. Turnovsky, Michelle and William Donnelly. 1984. "Energy Substitution, Separability, and Technical Progress in the Australian Iron and Steel Industry." Journal of Business \& Economic Statistics, 2: 54-63.

15. United States Government Printing Office 1964-1990. Economic Report of the President. United States Printing Office. Washington, D.C. 


\section{$\underline{\text { Notes }}$}

